\title{
Anti-TIM-3 Monoclonal Antibody TSR-022
}

National Cancer Institute

\section{Source}

National Cancer Institute. Anti-TIM-3 Monoclonal Antibody TSR-022. NCI Thesaurus.

Code C128627.

A monoclonal antibody ag ainst the inhibitory $\mathrm{T}$-cell receptor, $\mathrm{T}$-cell immunog lobulin and mucin domain-containing protein 3 (TIM-3; TIM3; hepatitis A virus cellular receptor 2; HAVCR2), with potential immune checkpoint inhibitory and antineoplastic activities. Upon administration, the anti-TIM-3 monoclonal antibody TSR-022 binds to TIM-3 expressed on certain T-cells, including tumor infiltrating lymphocytes (TILs). This abrogates T-cell inhibition, activates antigen-specific T-lymphocytes and enhances cytotoxic T-cellmediated tumor cell lysis, which results in a reduction in tumor growth. TIM-3, a transmembrane protein and immune checkpoint receptor, is associated with tumormediated immune suppression. 